\title{
Allometric Growth of the Flowers in Five Genera of the Marantaceae and in Canna (Cannaceae)
}

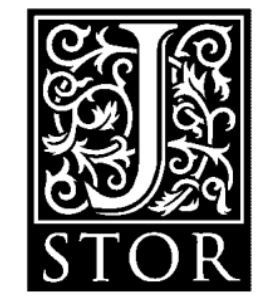

\author{
Bruce K. Kirchoff \\ Botanical Gazette, Volume 144, Issue 1 (Mar., 1983), 110-118. \\ Kirchoff, B. K.1983. Allometric growth of the flowers of five genera of the \\ Marantaceae and of Canna (Cannaceae). Botanical Gazette 144: 110-118. \\ Made available courtesy of University of Chicago Press: \\ http://www.journals.uchicago.edu/doi/abs/10.1086/337351
}

Your use of the JSTOR archive indicates your acceptance of JSTOR' s Terms and Conditions of Use, available at http://www.jstor.org/about/terms.html. JSTOR' s Terms and Conditions of Use provides, in part, that unless you have obtained prior permission, you may not download an entire issue of a journal or multiple copies of articles, and you may use content in the JSTOR archive only for your personal, non-commercial use.

Each copy of any part of a JSTOR transmission must contain the same copyright notice that appears on the screen or printed page of such transmission.

Botanical Gazette is published by University of Chicago Press. Please contact the publisher for further permissions regarding the use of this work. Publisher contact information may be obtained at http://www.j stor. org/j ournal s/ucpress .html.

\section{Botanical Gazette}

(C)1983 University of Chicago Press

JSTOR and the JSTOR logo are trademarks of JSTOR, and are Registered in the U.S. Patent and Trademark Office. For more information on JSTOR contact jstor-info@ umich.edu.

C2001 JSTOR

http://www.jstor.org/ 


\title{
ALLOMETRIC GROWTH OF THE FLOWERS IN FIVE GENERA OF THE MARANTACEAE AND IN CANNA (CANNACEAE)
}

\author{
BRUCE K. KIRCHOFF'
}

Department of Botany, Louisiana State University, Baton Rouge, Louisiana 70803

\begin{abstract}
Allometry was used to compare differential growth of the floral organs in seven species of the Marantaceae and in Canna indica. Different relative sizes of the floral parts arose through changes in the allometric growth rates, not by extension or truncation of the period of allometric growth. Correlations were found between the allometric growth rates of the various floral organs and the relative sizes of these organs. Relative size of the floral parts that function in pollination showed the best correlations with their growth rates, suggesting that selection for the relative sizes of floral organs can influence the allometric growth rates of these organs. Principal component analysis showed that growth rates of those floral members that function in pollination do not change independently. Two methods of pollinator action are suggested to account for this phenomenon. Similarity in allometric growth rates did not reflect the traditional taxonomic treatment of the Marantaceae at the generic level.
\end{abstract}

\section{Introduction}

Allometry, the change in shape correlated with change in size (GOULD 1977), has been applied mainly by zoologists in the study of animal growth and form (HUXLEY 1932; GOULD 1966). Few studies of flower development beyond organogenesis have been undertaken. In an investigation of the development of cleistogamous and chasmogamous flowers in Lamium amplexicaule, LORD (1979, 1980, 1982) found that the difference in form of the corolla of these two types of flowers is caused not only by a lack of anthesis in the cleistogamous flower but also by a difference in allometric growth rates initiated early in development.

GOEBEL (1900) thought that many changes in flower morphology resulted from the arrest of growth along a specific developmental pathway. For instance, cleistogamous flowers were thought to develop in the same way as chasmogamous flowers up to the point at which they became arrested and failed to complete development. SINNOTT (1936), in his study of the growth of two races of bottle gourds, found that both races produced gourds of distinctly different sizes and shapes. However, a comparison of the equations for the allometric growth (length by width) of the gourds indicated that the allometric growth rates were identical. The different shapes, thus, were the result of different durations of growth, not different rates.

Studies on the interspecific or intergeneric variability in allometric growth rates have not been attempted for flowers. The present investigation

\footnotetext{
$r$ Present address and address for correspondence and reprints: Department of Botany, Hebrew University of Jerusalem, 91904 Jerusalem, Israel.

Manuscript received March 198'2; revised manuscript received July 1982.
}

was undertaken to provide this kind of information and to investigate how flowers with similar patterns of organogenesis (KIRCHOFF, in press) give rise to diverse floral forms by different allometric growth rates. In addition, correlations among certain allometric growth rates and correlations between these rates and the relative sizes (lengths) of the floral organs have suggested a closely controlled relationship among relative organ length, the growth rate of the organ, and the pollination system.

\section{ORGANOGRAPHY}

Both the Marantaceae and the Cannaceae have asymmetrical, hermaphroditic flowers with a perianth of two trimerous whorls, two trimerous andioecial whorls, and an inferior, trilocular ovary. The corolla, androecium, and style of both families are fused into a floral tube of variable length.

The functional androecium of taxa of both families consists of one anther with two fertile loculi. I support EICHLER's (1875) interpretation that the other two loculi of the anther and the remaining inner andioecial members are modified as petaloid staminodes (KIRCHOFF, in press). In the Cannaceae, the petaloid members of the inner androecial whorl are the labellum and the inner staminode (Pm 1965). In the Marantaceae, they are the hooded staminode, which encloses the style and stigma before pollination, and the callose staminode, against which the stigma and style rest after pollination (KENNEDY 1977). In both families, the petaloid attachment to the fertile loculi is called the petaloid appendage (fig. 1).

\section{Material and methods}

The floral organs of seven species of the Marantaceae (Ischnosiphon elegans, Pleiostachya pruinosa, Marantochloa purpurea, Calathea vinosa, Calathea lancifolia, Calathea leopardinia, and 
Monotagma plurispicatum) and of Canna indica (Cannaceae) were measured at various stages of growth. The equations for the allometric growth of these organs were then evaluated and the allometric constants used to determine the variation in allometric growth rates and correlations between these rates and relative organ size.

When possible, all measurements were taken from living flowers of plants in the Duke University greenhouses. Flower parts were measured at 1-mm intervals, beginning with flowers ca. 2-5 mm long and ending with mature flowers. The smaller floral buds were measured with a Wild dissecting microscope and an ocular micrometer; the larger floral buds were measured directly with a millimeter ruler. Except for I. elegans and M. plurispicatum, which were not available as live material, at least 50 flowers of each species were measured. Measurements of I. elegans and M. plurispicatum were taken from pickled specimens collected in Costa Rica and Brazil, respectively. Because these species were available in limited quantities, only 14 flowers of $I$. elegans and 20 of $M$. plurispicatum were measured.

Flowers from all species growing in the greenhouses, except $C$. indica, were measured during a single flowering season. Those of $C$. indica were measured during two seasons. Measurements of $I$. elegans and $M$. plurispicatum were taken from flowers collected at one locality each. No attempt was made to investigate the variability in growth rates by measuring material from more than one population. In most cases, all the flowers came from one individual.

Floral parts were measured from the tip of the organs to their insertion of the floral tube, or as the length of the organ (fig. 1). The petaloid appendage was measured to its insertion on the filament in both families. In the Marantaceae, the length of the cup-shaped stigma was also measured.

The data were transformed into natural logarithms to study allometric growth. Plots of the transformed data against several different repre sentations of floral size showed that the length from the tip of the petals to the top of the ovary (fig. 1, $L N P O)$ was the most suitable standard for the calculation of the allometric growth rates, as this measure of size increased continuously with the increase of all other variables. The total length of the floral bud could not be used because calyx growth stops while the other floral organs are still contained within the sepals. This caused discontinuities in allometric plots that used bud length as a standard. In most cases, the plots of the transformed lengths of the floral organs against the logarithm of LNPO were curves that could be approximated by two straight lines (fig. 2). For simplicity, only the first of these lines was used in studying the growth rates.

Many times it was not possible to determine the precise point at which allometric growth stopped by inspection. For this purpose, a simple statistical procedure was devised in consultation with Dr. D. BURDICK of the Department of Mathematics, Duke University. The following operations were performed until the best fit $\left(1^{2}\right)$ was found.

1. Fit the allometric equation $(\ln \mathrm{y}=k \ln x+$ $\ln b)$ to all of the points of the graph, where $\mathrm{y}$ is the length of a specific floral organ, $\mathrm{x}$ is $L N P O, k$ is the allometric growth rate, and $b$ is a constant. Record the value of $r^{2}$.

2. Take the observation with the highest value of $L N P O$ and change this value to the next lower value of $L N P O$ for some other observation. This clusters the observation(s) with the largest value of $L N P O$ with the observation with the next lower $L N P O$ value.

3. Repeat steps 1 and 2 as many times as necessary to find the maximum $r^{2}$.

The algorithm gave the number of points (no. $=$ number of flowers measured - number of iterations of the algorithm) at which $\mathbf{r}^{2}$ was a maximum. Once this was determined, the allometric equation was fitted only to this number of points.
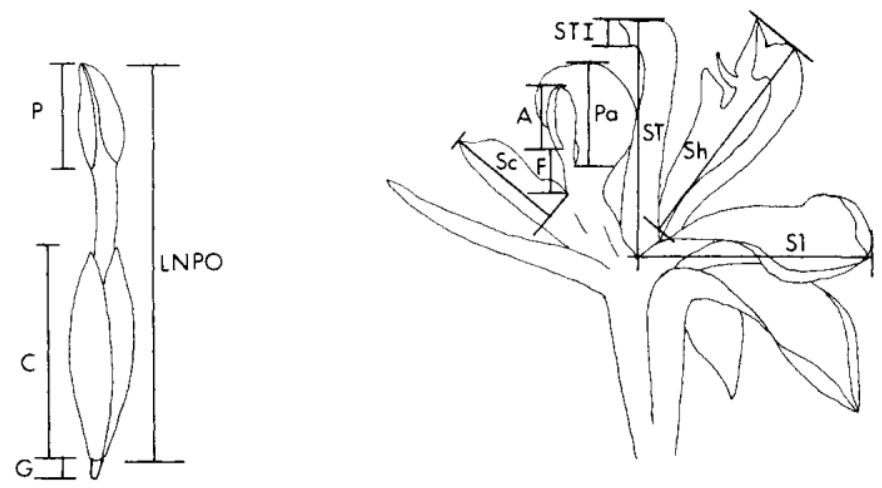

FIG. 1.-Measurements of floral parts illustrated for an imaginary species of the Marantaceae. $P=$ petals; $C=$ sepals; $G=$ ovary; $L N P O=$ length from tip of petals to top of ovary; $S c=$ callose staminode; $A=$ anther; $F=$ filament; $P a=$ petaloid appendage to the anther; $S T I=$ stigma; $S T=$ style; $S h=$ hooded staminode; $S 1=$ outer staminode. 
studied (table 1). No attempt was made to fit a line to points not included in the determination of the initial lines.

The slopes (k's) of the regression lines were tested for correlations with various measures of organ and flower size. It was assumed that the allometric growth rates were normally distributed. Many measures of floral size were checked for correlations with the allometric growth rates.

The allometric growth rates were also used in a principal components analysis (PCA) to test for the independence of the allometric growth rates (the variables) of the various floral organs among species (the observations). These analyses, as well as the determination of the point at which allometric growth stops, were performed by the Statistical Analysis System (SAS) (HELWIG and COUNCIL 1979). PROC CLUSTER of SAS (a hierarchical clustering technique) was also used to group the taxa on the basis of similarity of the growth rates among taxa. The distance matrix calculated by PROC CLUSTER was not standardized.

\section{Results}

\section{FLORAL GROWTH}

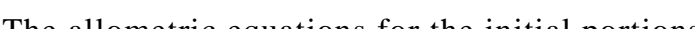

of floral growth (table 1) demonstrate a unique pattern of allometric growth for each species. Homologous organs of different species seldom have similar allometric growth rates. This is in contrast to the similar patterns of organogenesis that have been described for these species (figs. 4-6) (KIRCHOFF, in press) but reflects the great diversity of floral shape (figs. 7-14) and size (table 3) for the mature flowers.

The results of PCA (table 2) show that the allometric growth rates for those floral organs (petals, outer staminode, callose staminode/inner staminode, hooded staminode/labellum, style) that play a role in pollination are all correlated with the first principal component (PC1). The allometric growth rates of the sepals and of the anther are the only rates correlated with the second and third components, respectively. No significant correlations were found between the growth rate of the ovary and any of the principal components.

To determine whether the patterns of allometric growth for the genera of the Marantaceae and Cannaceae reflect the traditional taxonomic treatments of these genera, I used PROC CLUSTER of SAS to group the genera on the basis of similarity of overall pattern of allometric growth: similarities in

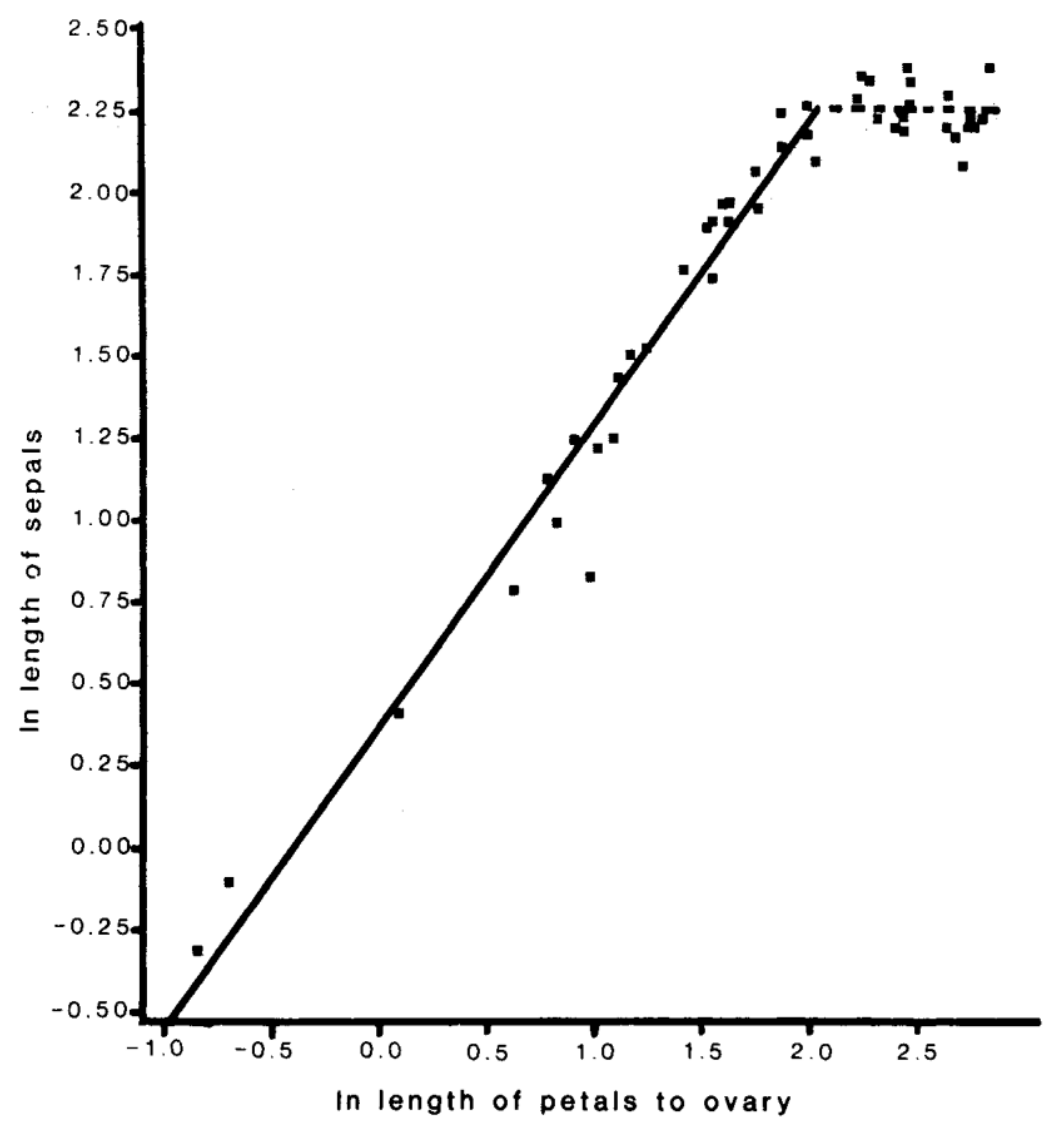

FIG. 2.-Allometric plot of sepal growth in Marantochloa purpurea. The curvilinear plot is approximated by two straight lines. The solid line is fitted by least squares, while the dotted line is drawn at the mean of the points not included in the determination of the first line. 
allometric growth rates cut across traditional taxonomic boundaries (fig. 3).

Attempts to correlate the allometric growth rates with some measure of floral size indicated positive correlations between the relative sizes of those organs that play a role in pollination and their allometric growth rates. The growth rates of the petals, outer staminode, callose staminode (inner staminode, Canna), hooded staminode (labellum, Canna), and style are correlated with their relative sizes at maturity. The growth rates of the sepals, stigma, ovary, anther, and filament are not.

Correlations within species for relationships between the size of the various floral organs and their allometric growth rates were calculated. No measure of floral or organ size is correlated with the allometric growth rates of the floral organs for any of the species of the Marantaceae. However, the mature length of the floral organs, the length of the floral organs at the end of the period of allometric growth, and the length of LNPO at the end of allometric growth are all correlated with the growth rates in Canna indica.

\section{Discussion}

All of the species except Ischnosiphon elegans and Pleiostachya pruinosa show unique patterns of organogenesis but share a basic similarity in developmental patterns (KIRCHOFF, in press). Except for the formation of the calyx, the sequences of organ formation in the Marantaceae and Cannaceae are identical. In the Cannaceae, sepals and succeeding parts lie on the same ontogenetic spiral; in the Marantaceae, the calyx and corolla spirals are opposite. Apart from this difference, the only variability in the patterns of organogenesis is found in the formation of the inner androecium.

The inner androecial members and their associated petals arise through the division of common primordia on the floral dome. In general, this separation occurs through the initiation of two growth centers at the same level in the ventral and dorsal flanks of the common primordia. The ventral member of this pair gives rise to the androecial member, while the dorsal produces the petal. Ischnosiphon elegans, P. pruinosa, Marantochloa purpurea, and Canna indica show a significant deviation from this general pattern in one androecial member. In $I$. elegans and $P$. pruinosa, the stamen is initiated in the ventral flank of the common primordium, below the level of petal initiation. Marantochloa purpurea and $C$. indica show a similar pattern of initiation of the callose staminode and petal: the staminode is initiated in the ventral flank of the common primordium below the petal.

The similarity in the patterns of organogenesis in the Marantaceae and Cannaceae is reflected in the shape of the floral apices at the time of gynoecial initiation (figs. 4-6). With only this floral stage for comparison, it would be difficult to tell the species or genera of the Marantaceae apart. Although $C$. indica is also similar to the species of the Marantaceae at this stage, it can be distinguished by the oval shape of the floral apex (fig. 6).

The basic similarities in initiation patterns contrast sharply with the diversity of mature floral forms in the studied genera (figs. 7-14). The flowers of $M$. purpurea (fig. 13), the smallest flowers studied, reach a maximum size of $19 \mathrm{~mm}$, while the largest are those of $C$. indica (fig. 14), which reach $65 \mathrm{~mm}$. The maximum sizes for the flowers of all other species are between these extremes (table 3 ).

How this great diversity of mature floral shapes and sizes arises from basically similar patterns of organogenesis may be partially answered by considering the allometric growth rates of the various floral parts (table 1). Flowers that begin growth with similar floral shapes but differ in the allometric growth rates of their parts will diverge in shape as they increase in size: this occurs in the flowers of the Marantaceae and Cannaceae. The initially similar developmental stages develop into mature flowers through a process of allometric growth that is unique to each species (table 1). Seldom is the allometric constant $(k)$ equal for homologous organs in different species (table $1 ; k=$ 1.39 for the growth of the callose staminode in $I$. elegans and P. pruinosa), and, even in these plants, the allometric constants for the other floral organs vary.

When the allometric coefficients for all of the floral organs of one species are compared with those of all other species, a clustering of species based on similarity of all growth rates is obtained (fig. 3). The most important point illustrated by this procedure is that the three species of Calathea do not cluster. Calathea leopardinia clusters with M. purpurea, P. pruinosa, and I. elegans, while Calathea lancifolia and Calathea vinosa cluster with Monotagma plurispicatum. Thus, at least in this simple case of organ length by $L N P O$, similarity in allometric growth rates cuts across generic boundaries.

There are two exceptions to the rule that similarity in allometric growth rates and traditional classification vary. First, P. pruinosa and I. elegans form a cluster, supporting previous taxonomic work (ANDERSSON 1977, 1981) which has always suggested that Ischnosiphon and Pleiostachya are very closely related. Second, $C$. indica does not cluster with any subgroup of the Marantaceae, supporting the placement of these two genera in different families.

Most correlations occur between the parts of the flower that play a role in pollination and the relative sizes of these organs (a measure of shape), suggesting that selection for different relative sizes influences the allometric growth rates of these organs. I suggest that the relative lengths of the floral parts, and thus at least one aspect of floral shape, come about through a change in the allometric 
TABLE 1

REGRESSION EQUATIONS FOR ALLOMETRIC GROWTH OF VARIOUS FLORAL ORGANS

\begin{tabular}{|c|c|c|c|c|}
\hline Measurement and species $\mathrm{s}^{\mathrm{a}}$ & Equation & & & No. \\
\hline \multicolumn{5}{|c|}{ Calyx length $\times$ length from tip of petals to ovary: } \\
\hline 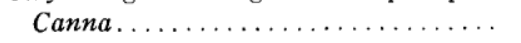 & $\ln y=.80 \ln x$ & +2.33 & .96 & 38 \\
\hline Monotagma ................ & $\ln y=1.09 \ln x$ & +.48 & .99 & 9 \\
\hline Calathea vinosa $\ldots \ldots \ldots \ldots \ldots \ldots$ & $\ln y=1.48 \ln x$ & -.60 & .97 & 52 \\
\hline C. leopardinia................ & $\ln y=1.93 \ln x$ & -1.26 & .97 & 13 \\
\hline C. lancifolia $\ldots \ldots \ldots \ldots \ldots \ldots$ & $\ln y=1.20 \ln x$ & -.18 & .99 & 22 \\
\hline 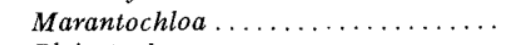 & $\ln y=.92 \ln x$ & +.36 & .98 & 30 \\
\hline Pleiostachya ............... & $\ln y=1.35 \ln x$ & -.08 & .99 & 41 \\
\hline Ischnosiphon................ & $\ln y=1.24 \ln x$ & -.47 & .98 & 10 \\
\hline \multicolumn{5}{|c|}{ Corolla length $\times$ length from tip of petals to ovary: } \\
\hline 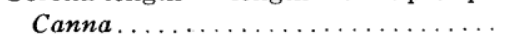 & $\ln y=.99 \ln x$ & -.02 & .99 & 48 \\
\hline Monotagma ................ & $\ln y=.65 \ln x$ & +2.18 & .98 & 20 \\
\hline Calathea vinosa ................. & $\ln y=.70 \ln x$ & +.21 & .98 & 58 \\
\hline C. leopardinia.................. & $\ln y=.66 \ln x$ & +.32 & .99 & 41 \\
\hline C. lancifolia $\ldots \ldots \ldots \ldots \ldots \ldots$ & $\ln y=.63 \ln x$ & +.46 & .99 & 46 \\
\hline 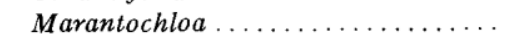 & $\ln y=.96 \ln x$ & -.06 & .99 & 45 \\
\hline Pleiostachya ............... & $\ln y=.77 \ln x$ & +.20 & .98 & 40 \\
\hline 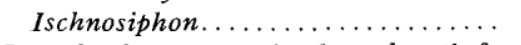 & $\ln y=.64 \ln x$ & +.39 & .99 & 12 \\
\hline \multicolumn{5}{|c|}{ Length of outer staminode $\times$ length from tip of petals to ovary: } \\
\hline 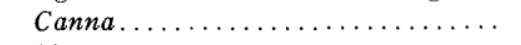 & $\ln y=2.35 \ln x$ & -5.53 & .99 & 64 \\
\hline Monotagma ................ & $\ln y=1.07 \ln x$ & -1.22 & .98 & 17 \\
\hline Calathea vinosa $\ldots \ldots \ldots \ldots \ldots \ldots$ & $\ln y=1.38 \ln x$ & -2.14 & .97 & 58 \\
\hline C. leopardinia................ & $\ln y=2.23 \ln x$ & -3.12 & .99 & 19 \\
\hline C. lancifolia $\ldots \ldots \ldots \ldots \ldots \ldots \ldots$ & $\ln y=1.72 \ln x$ & -2.60 & .97 & 24 \\
\hline 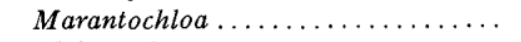 & $\ln y=1.89 \ln x$ & -2.85 & .98 & 41 \\
\hline Pleiostachya ................ & $\ln y=1.85 \ln x$ & -2.70 & .99 & 29 \\
\hline Ischnosiphon................. & $\ln y=1.36 \ln x$ & -2.16 & .97 & 12 \\
\hline \multicolumn{5}{|c|}{ Length of hooded staminode (labellum) $\times$ length from tip of petals to ovary: } \\
\hline 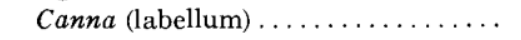 & $\ln y=1.95 \ln x$ & -4.04 & .99 & 64 \\
\hline Monotagma ................ & $\ln y=1.02 \ln x$ & -.92 & .96 & 13 \\
\hline Calathea vinosa $\ldots \ldots \ldots \ldots \ldots \ldots$ & $\ln y=1.20 \ln x$ & -1.37 & .98 & 57 \\
\hline C. leopardinia............... & $\ln y=1.41 \ln x$ & -2.10 & .99 & 25 \\
\hline C. lancifolia $\ldots \ldots \ldots \ldots \ldots \ldots$ & $\ln y=.79 \ln x$ & -.80 & .96 & 37 \\
\hline 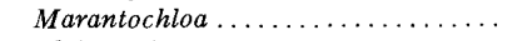 & $\ln y=1.36 \ln x$ & -1.76 & .98 & 48 \\
\hline Pleiostachya ................ & $\ln y=1.12 \ln x$ & -1.53 & .98 & 36 \\
\hline 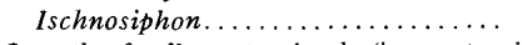 & $\ln y=1.20 \ln x$ & -1.93 & .99 & 12 \\
\hline \multicolumn{5}{|c|}{ Length of callose staminode (inner staminode) $\times$ length from tip of petals to ovary: } \\
\hline Canna (inner staminode) ........... & $\ln y=2.53 \ln x$ & -6.38 & .97 & 64 \\
\hline 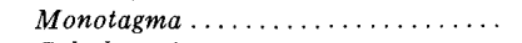 & $\ln y=1.23 \ln x$ & -1.50 & .98 & 16 \\
\hline 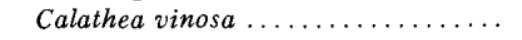 & $\ln y=1.25 \ln x$ & -1.72 & .98 & 58 \\
\hline C. leopardinia................. & $\ln y=1.91 \ln x$ & -2.52 & .99 & 19 \\
\hline C. lancifolia $\ldots \ldots \ldots \ldots \ldots \ldots$ & $\ln y=1.30 \ln x$ & -1.54 & .98 & 22 \\
\hline Marantochloa ................ & $\ln y=1.50 \ln x$ & -2.04 & .98 & 44 \\
\hline Pleiostachya ................ & $\ln y=1.39 \ln x$ & -2.33 & .99 & 41 \\
\hline Ischnosiphon................... & $\ln y=1.39 \ln x$ & -2.18 & .98 & 12 \\
\hline \multicolumn{5}{|c|}{ Anther length $\times$ length from tip of petals to ovary: } \\
\hline 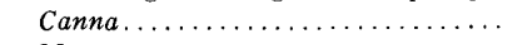 & $\ln y=.69 \ln x$ & -.05 & .99 & 24 \\
\hline Monotagma ................. & $\ln y=1.04 \ln x$ & -.84 & .96 & 9 \\
\hline Calathea vinosa ................ & $\ln y=1.00 \ln x$ & -.63 & .97 & 37 \\
\hline C. leopardinia................ & $\ln y=.77 \ln x$ & -.69 & .98 & 12 \\
\hline C. lancifolia $\ldots \ldots \ldots \ldots \ldots \ldots \ldots$ & $\ln y=.46 \ln x$ & -.29 & .99 & 13 \\
\hline 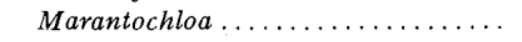 & $\ln y=1.12 \ln x$ & -.76 & .99 & 17 \\
\hline Pleiostachya ................ & $\ln y=.96 \ln x$ & -.41 & .98 & 14 \\
\hline Ischnosiphon................ & $\ln y=1.48 \ln x$ & -1.30 & .99 & 7 \\
\hline \multicolumn{5}{|c|}{ Style length $\times$ length from tip of petals to ovary: } \\
\hline 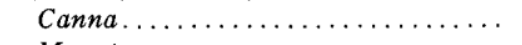 & $\ln y=1.93 \ln x$ & -4.44 & .98 & 64 \\
\hline 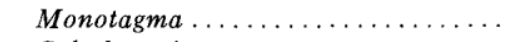 & $\ln y=.94 \ln x$ & -1.48 & .97 & 17 \\
\hline Calathea vinosa ................. & $\ln y=1.16 \ln x$ & -2.07 & .97 & 83 \\
\hline C. leopardinia................ & $\ln y=1.58 \ln x$ & -3.17 & .99 & 42 \\
\hline C. lancifolia $\ldots \ldots \ldots \ldots \ldots \ldots$ & $\ln y=1.41 \ln x$ & -2.98 & .99 & 48 \\
\hline 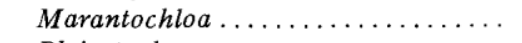 & $\ln y=2.00 \ln x$ & -3.53 & .99 & 48 \\
\hline Pleiostachya ............ & $\ln y=1.31 \ln x$ & -2.67 & .99 & 53 \\
\hline Ischnosiphon............. & $\ln y=1.33 \ln x$ & -3.31 & .97 & $\varepsilon$ \\
\hline
\end{tabular}


TABLE 1 (Continued)

\begin{tabular}{|c|c|c|c|}
\hline Measurenient and ssecters" & Ечи:анон & & No. \\
\hline \multicolumn{4}{|c|}{ Ovary length $\times$ length from tip of petals to ovary: } \\
\hline 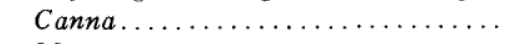 & $\ln y=.91 \ln x-1.94$ & .96 & 45 \\
\hline 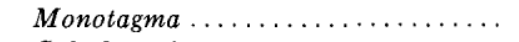 & $\ln y=.36 \ln x-.53$ & .96 & 12 \\
\hline Calathea vinosa ................ & $\ln y=.49 \ln x-.70$ & .92 & 68 \\
\hline C. leopardinia................ & $\ln y=1.55 \ln x-1.91$ & .97 & 16 \\
\hline C. lancifolia $\ldots \ldots \ldots \ldots \ldots \ldots$ & $\ln y=.56 \ln x-1.06$ & .97 & 22 \\
\hline Marantochloa ................ & $\ln y=.88 \ln x-1.31$ & .95 & 18 \\
\hline Pleiostachya .................. & $\ln y=.94 \ln x-1.66$ & .98 & 29 \\
\hline Ischnosiphon................. & $\ln y=.95 \ln x-.69$ & .97 & 9 \\
\hline \multicolumn{4}{|c|}{ Stigma length $\times$ length from tip of petals to ovary: } \\
\hline 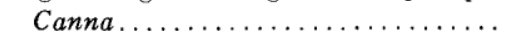 & No comparable measurement & $\ldots$ & $\ldots$ \\
\hline Monotagma ................... & $\ln y=1.04 \ln x-1.29$ & .94 & 10 \\
\hline Calathea vinosa $\ldots \ldots \ldots \ldots \ldots \ldots$ & $\ln y=1.28 \ln x-2.02$ & .98 & 36 \\
\hline C. leopardinia.................. & $\ln y=1.06 \ln x-1.86$ & .96 & 13 \\
\hline C. lancifolia .................. & $\ln y=.70 \ln x-1.40$ & .84 & 15 \\
\hline Marantochloa ................. & $\ln y=1.15 \ln x-2.06$ & .98 & 30 \\
\hline Pleiostachya ................. & $\ln y=.88 \ln x-1.84$ & .96 & 18 \\
\hline Ischnosiphon................ & $\ln y=.82 \ln x-1.77$ & .86 & 8 \\
\hline \multicolumn{4}{|c|}{ Filament length $\times$ length from tip of petals to ovary: } \\
\hline 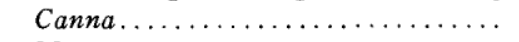 & No comparable measurement & $\ldots$ & . . \\
\hline Monotagma .................. & $\ln y=1.54 \ln x-3.24$ & .97 & 12 \\
\hline Calathea vinosa ................ & $\ln y=1.91 \ln x-5.67$ & .92 & 56 \\
\hline C. leopardinia.................. & $\ln y=1.68 \ln x-4.64$ & .86 & 29 \\
\hline C. lancifolia ................. & $\ln y=1.36 \ln x-3.68$ & .95 & 37 \\
\hline Marantochloa ................ & $\ln y=1.86 \ln x-3.52$ & .98 & 41 \\
\hline Pleiostachya ................. & $\ln y=1.85 \ln x-5.06$ & .96 & 37 \\
\hline Ischnosiphon................ & $\ln y=1.31 \ln x-3.51$ & .98 & 12 \\
\hline \multicolumn{4}{|c|}{ Length of petaloid appendage to anther $\times$ length from tip of petals to ovary: } \\
\hline 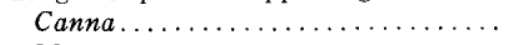 & $\ln y=3.38 \ln x-9.95$ & .98 & 38 \\
\hline 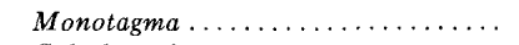 & No comparable measurement & $\cdots$ & $\cdots$ \\
\hline Calathea vinosa ............... & No comparable measurement & $\ldots$ & . . \\
\hline C. leopardinia..... & $\ln y=1.56 \ln x-5.72$ & .88 & 60 \\
\hline C. lancifolia ....... & No comparable measurement & $\cdots$ & $\cdots$ \\
\hline Marantochloa ............ & $\ln y=2.27 \ln x-4.43$ & .98 & 34 \\
\hline 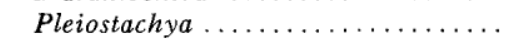 & $\ln y=1.41 \ln x-2.98$ & .96 & 39 \\
\hline 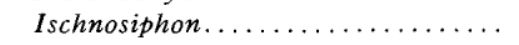 & $\ln y=1.78 \ln x-5.47$ & .97 & 8 \\
\hline
\end{tabular}

a Species: Canna indica, Monotagma plurispicatum, Calathea vinosa, C. leopardinia, C. lancifolia, Marantochloa purpurea, Pleiostachya pruinosa, Ischnosiphon elegans.

TABLE 2

CORRELATIONS OF ALLOMETRIC GROWTH RATES WITH PRINCIPAL COMPONENTS (PC)

\begin{tabular}{|c|c|c|c|c|c|c|}
\hline \multirow{2}{*}{$\begin{array}{l}\text { ALLOMETRICALLY } \\
\text { GROWING ORGAN }\end{array}$} & \multicolumn{2}{|c|}{$\mathrm{PC} 1$} & \multicolumn{2}{|c|}{$\mathrm{PC} 2$} & \multicolumn{2}{|c|}{$\mathrm{PC} 3$} \\
\hline & $r$ & Significant $^{\mathrm{a}}$ & $r$ & Significant $^{\mathrm{a}}$ & $r$ & Significant $\mathrm{t}^{\mathrm{a}}$ \\
\hline Petals. . . . . . . . . . . . & -.73 & + & .51 & - & .02 & - \\
\hline Outer staminode $\ldots \ldots \ldots \ldots$ & -.93 & + & -.27 & - & -.11 & - \\
\hline Callose staminode $\ldots \ldots \ldots$ & -.94 & + & .04 & - & .02 & - \\
\hline Hooded staminode. . . . . . . . & -.86 & + & .22 & - & .25 & - \\
\hline Style .............. & -.87 & + & .19 & - & .03 & - \\
\hline Sepals ............... & .18 & - & -.94 & + & .23 & - \\
\hline Anther $\ldots \ldots \ldots \ldots \ldots \ldots$ & .35 & - & .33 & - & .87 & + \\
\hline Ovary $\ldots \ldots \ldots \ldots \ldots \ldots$ & .68 & - & -.36 & - & .52 & - \\
\hline
\end{tabular}

a Assessed at the .05 level. 


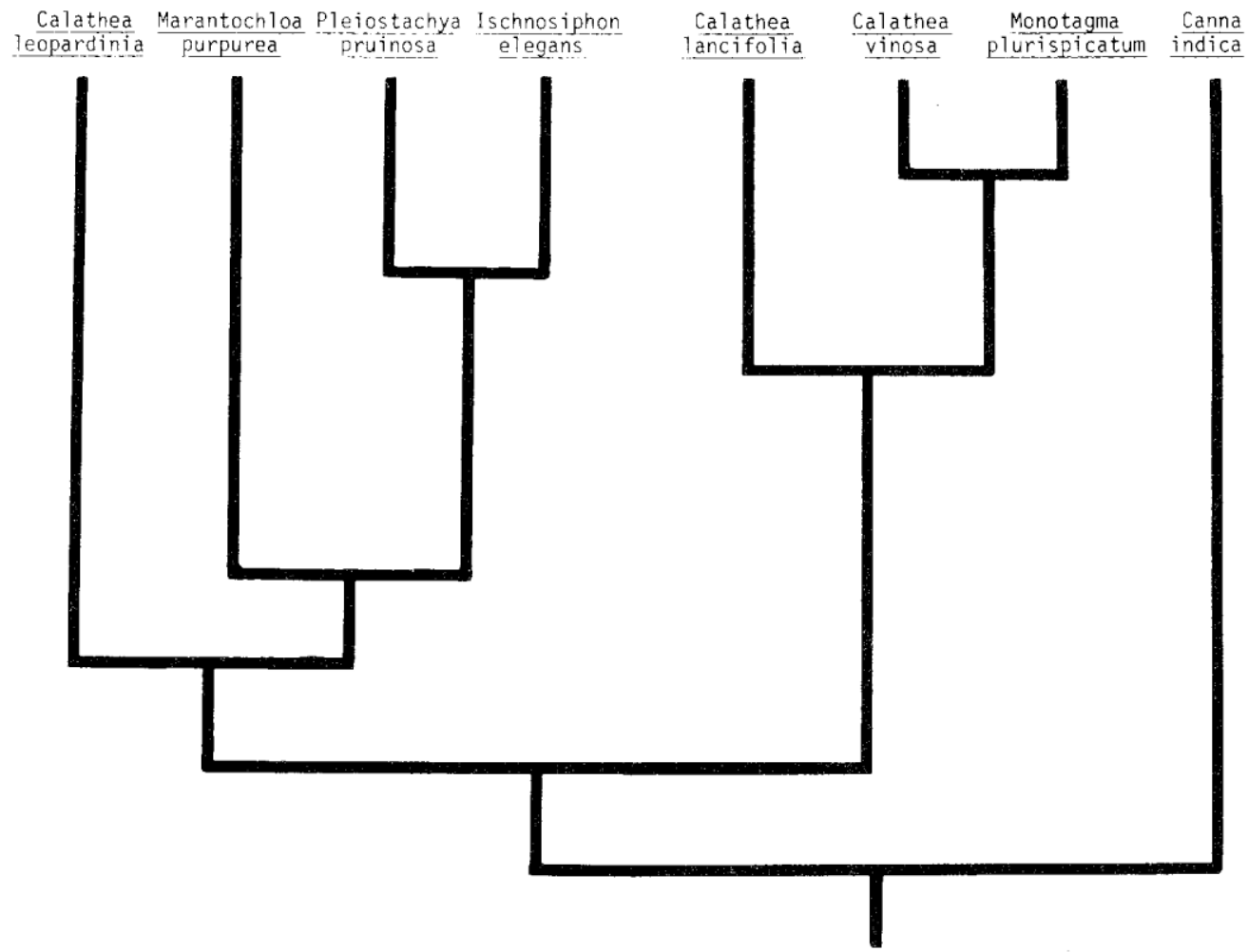

FIG. 3.-Clustering of species based on similarity of allometric growth rates
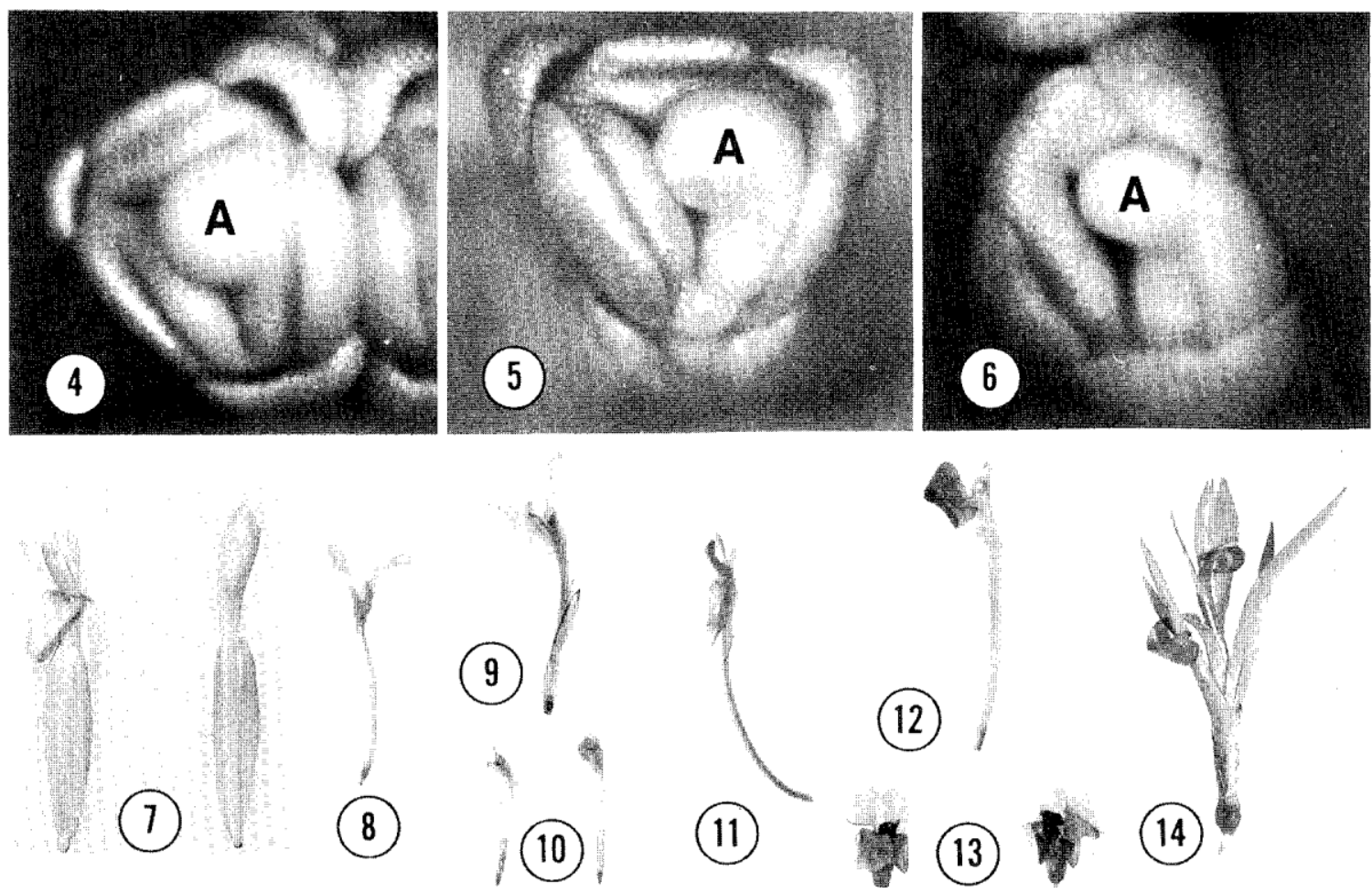

Figs. 4-14.-Figs. 4-6, Floral apices at the stage of gynoecial initiation. $A=$ anther. Fig. 4, Pleiostachya pruinosa; $\times 131$. Fig. 5, Monotagma phrispicatum; $\times$ 168. Fig. 6, Canna indica; $\times 125$. Figs. $7-14$, Mature flowers. Fig. 7 , Calathea vinosa; $\times$ 0.6. Fig. 8, Calathea leopardinia; $\times$ 0.6. Fig. 9, Calathea lancifolia; $\times 0.6$. Fig. 10, Monotagma plurispicatum; $\times 0.6$. Fig. 11, Ischnosiphon elegans; $\times$ 0.6. Fig. 12, Pleiostachya pruinosa; $\times 0.6$. Fig. 13, Marantochloa purpurea; $\times 0.6$. Fig. 14, Canna indica; $\times 0.6$. 
TABLE 3

MAXIMUM FLORAL SIZES

\begin{tabular}{|c|c|}
\hline Species & Size $(\mathrm{mm})$ \\
\hline Ischnosiphon elegans .............. & 60.2 \\
\hline Pleiostachya pruinosa............... & 49.5 \\
\hline Marantochloa purpurea .............. & 19.2 \\
\hline 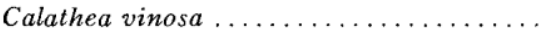 & 63.0 \\
\hline C. lancifolia $\ldots \ldots \ldots \ldots \ldots \ldots$ & 51.9 \\
\hline C. leopardinia.................... & 40.0 \\
\hline Monotagma plurispicatum ............ & 28.2 \\
\hline 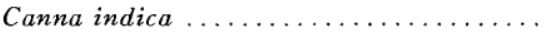 & 65.0 \\
\hline
\end{tabular}

growth rates of the floral organs and not through an extension or truncation of the period of allometric growth. For example, a petal with a larger than average relative length would be produced, not by a simple extension of the amount of time the petal grows, but by a change in the allometric rate at which it grows. If pollinators preferentially visit the flowers with this new petal length, the predominant floral shape in the population will shift, as will the predominant allometric rate of petal growth. Thus, speciation should be associated with a shift in the allometric growth rates of the floral organs that function in pollination, and interspecific correlations will be found between the allometric growth rates and relative sizes of these organs.

The results of PCA on the allometric growth rates of the floral organs allow an extension of the proposed hypothesis. The growth rates of the floral organs active in pollination are correlated with PC1, suggesting that interspecific changes in these rates have not occurred independently (table 2). The correlation of growth rates for these organs with their relative sizes at maturity indicates that only species with correlated relative organ sizes are produced. Thus, selection pressures that operate to change this aspect of floral shape also operate to change the allometric growth rates of the floral organs. In other words, the flowers of the Marantaceae and Cannaceae appear to have evolved as functional units with respect to pollination. It is highly likely that the success of pollination depends on the relative size of all the attractive parts of the flower considered as a unit, not on the relative size of the individual parts.

Two methods of pollinator action could cause the correlation of allometric growth rates. First, pollinators may have a preference for flowers that show correlated allometric growth rates. They would not discriminate between flowers on this basis but on the basis of the shape of the flower (measured by the relative size of the parts in this study), which is correlated with these rates. Second, there may be no pollinator discrimination, but a greater percentage of effective pollinations may occur in those flowers that show correlated rates. This increased number of effective pollinations would be a function of pollen placement on the insect, an operation that appears to be tightly controlled in the Marantaceae (KENNEDY 1977).

If the second method of selection occurs in the Marantaceae and Cannaceae, it explains the correlation of the allometric growth rate of the style with PC1. In the Marantaceae, the style functions in the placement of pollen on the insect (KENNEDY 1977); thus, the relative size of the style is an extremely important variable for effective pollination. Changes in its length without corresponding changes in the lengths of the other floral parts would most likely prevent effective pollination.

Besides the organs that function directly in pollination, two other organs have allometric growth rates that correlate with one of the principal components: the growth of the sepals correlates with PC2 and that of the anther with PC3 (table 2). In both instances, these are the only organs whose rates of growth correlate with these axes. This shows that the allometric growth rates of the sepals and anther are independent of each other and are also independent of the growth rates of the organs that cluster on PC1. Thus, the allometric growth rates of these three groups of organs can change independently, in marked contrast to the organs that cluster on PC1 that do not change allometric growth rates independently.

In addition to being independent, the allometric growth rates of the anther and sepals are not correlated with the relative sizes of these organs at maturity. Thus, changes in relative size of these organs cannot be explained through changes in their allometric growth rates alone; nor can selection for organs of different relative size produce correlated changes in these rates.

The intraspecific correlations relate the allometric growth rates of the various floral organs of a species to the size of these organs. The lack of within-species correlations in the Marantaceae and the presence of these correlations in $C$. indica suggest that some change in the relationship between growth and size has occurred in the evolution of the Marantaceae and Cannaceae. This change may be related to a shift in pollinators from predominantly hummingbird pollinators for C. indica $(W$. J. KRESS, personal communication) to Euglossine bees in the New World Marantaceae (KENNEDY 1977). If this supposition is correct, then other species pollinated by hummingbirds should show the same type of correlations as $C$. indica, and these correlations should not be present in other beepollinated flowers. The Heliconiaceae (hummingbird pollination) and Costaceae (hummingbird and bee pollination; W. J. KRESS, personal communication) are excellent families to test this hypothesis, as they have similar pollinators to $C$. indica and 
the Marantaceae and are members of the same order (Zingiberales).

\section{Acknowledgments}

This paper is based on a portion of a dissertation submitted in partial fulfillment of the requirements for the degree of Doctor of Philosophy in the Department of Botany of the Duke University Graduate School. I am deeply grateful to Dr. RICHARD A. WHITE for his support and guidance during the completion of my dissertation. I am also grateful to Dr. DOUGLAS SCHEMSKE and an unidentified reviewer for their suggestions to improve the manuscript. Dr. DONALD BURDICK, ELLEN SIMMS, and TOM COULTON assisted in the statistical analyses. Dr. SHIRLEY TUCKER read several versions of the manuscript and provided many helpful criticisms. I am indebted to Dr. G. PRANCE of the New York Botanical Garden for supplying material of Monotagma plurispicatum from Brazil, and to SALLY BAKER for drawing figure 1 .

\section{LITERATURE CITED}

ANDERSSON, L. 1977. The genus I schnosiphon (Marantaceae). Opera Bot. 43:1-113. 1981. The neotropical genera of Marantaceae: circum scription and relationships. Nord. J. Bot. 1:218-245. EICHLER, A. W. 1875. Blüthendiagramme construirt and erlautert. Vol. 1. Engelmann, Leipzig.

GOEBEL, K. 1900. Organography of plants. Pt. 1. General organography. Clarendon, Oxford.

GOULD, S. J. 1966. Allometry and size in ontogeny and phylogeny. Biol. Rev. 41:587-640. 1977. Ontogeny and phylogeny. Harvard University Press, Cambridge, Mass.

HELWIG, J. T., and K. A. COUNCIL. 1979. SAS user's guide. 1979 ed. SAS Institute, Raleigh, N.C.

HUXLEY, J. 1932. Problems of relative growth. Methuen, London.

KENNEDY, H. 1977. Systematics and pollination of the "closedflowered" species of Calathea (Marantaceae). Univ. California
Pub. Bot. 71;1-90.

KIRCHOFF, B. K. In press. Floral organogenesis in five species of the Marantaceae and in Canna (Cannaceae). Amer. J. Bot. LORD, E. 1979. The development of cleistogamous and chasmogamous flowers in Lamium amplexicaule (Labiatae): an example of heteroblastic inflorescence development. BOT. GAZ. 140:39-50.

1980. An anatomical basis for the divergent floral forms in the cleistogamous species, Lamium amplexicaule L. (Labiatae). Amer. J. Bot. 67:1430-1441.

. 1982. Floral morphogenesis in Lamium amplexicaule

L. (Labiatae) with a model for the evolution of the cleistogamous flower. BOT. GAZ. 143:63-72.

PAI, R. M. 1965. Morphology of the flower in the Cannaceae. J. Biol. Sci. 8:4-8.

SINNOTT, E. 1936. A developmental analysis of inherited shape differences in cucurbit fruits. Amer. Natur. 70:245-254. 